\title{
Erratum to: Stability Analysis of Markovian Jump Systems
}

\section{Erratum to: \\ Y. Kang et al., Stability Analysis of Markovian Jump Systems, https://doi.org/10.1007/978-981-10-3860-0}

In the original version of the book, the text "Not for sale outside the Mainland of China (Not for sale in Hong Kong SAR, Macau SAR, and Taiwan, and all countries, except the Mainland of China)." has to be changed as "The printed edition is not for sale in China Mainland. Customers from China Mainland please order the print book from Science Press, Beijing, China." in the Copyright page. The erratum book has been updated with the change.

The updated online version of this book can be found at https://doi.org/10.1007/978-981-10-3860-0 